\title{
Cultural considerations for Canadians in the diagnosis of brain death
}

\section{[Aspects culturels du diagnostic de mort cérébrale au Canada]}

Kerry W. Bowman MSW PhD, Shawn A. Richard MA

Purpose: This articles explores cultural perceptions and values related to brain death and organ donation from both a Western and non-Western perspective.

Source: Anthropological literature review of the historical concept of brain death in Canada using Eastern culture as a comparison.

Principal findings: Although the concept of brain death and concomitant organ donation have become widely practiced in Western nations such as Canada, from a cross-cultural point of view these concepts and practices can be deeply troubling and may hold profoundly different meaning to people new to Canada.

Conclusions: Canada has a deep commitment and obligation to respect diversity as reflected in the Canadian Charter of Rights and Freedoms. Therefore, healthcare workers have an obligation to respect cultural differences. To truly respect cultural differences we must first explore our own culturally formulated belief systems and then consider how our views may interface with other cultures. Our findings call for a greater analysis of the cultural influences on the concept of brain death and organ donation as a means of building a better understanding and respect for cultural diversity.

Objectif : Explorer les perceptions et les valeurs culturelles reliées à la mort cérébrale et au don d'organe selon une perspective occidentale et non occidentale.

Source : La revue des publications anthropologiques sur le concept historique de mort cérébrale au Canada en utilisant la culture orientale comme point de comparaison.

Constatations principales : Même si le concept de mort cérébrale et de don d'organe simultané sont largement mis en pratique dans les pays occidentaux comme la Canada, ces concepts et ces pratiques peuvent, d'un point de vue transculturel, être profondément troublants et peuvent présenter une signification très différente à des gens nouvellement arrivés au Canada.

Conclusion : Le Canada accorde une grande importance à la diversité culturelle et se fait un devoir de la respecter comme le montre la Charte canadienne des droits et libertés. En conséquence, les tra- vailleurs de la santé ont l'obligation de respecter ces différences. Pour y arriver vraiment, nous devons d'abord explorer nos propres systèmes de valeurs culturelles et considérer ensuite comment nos points de vue sont liés aux autres cultures. Nos constatations nous amènent à souhaiter une analyse plus importante des influences culturelles sur le concept de mort cérébrale et de don d'organe comme moyen de favoriser une meilleure compréhension et un plus grand respect de la diversité culturelle.

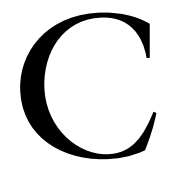

ANADA has adopted a view of diversity in which ethnic identities are respected, maintained, encouraged and celebrated. Diversity is seen as creating a cultural mosaic, a national cohesiveness and sense of identity. ${ }^{1,2}$ This notion of pluralism as a patchwork of cultures has steadily evolved through waves of immigration, creating a sense of national identity that is deeply reflected in the Canadian Charter of Rights and Freedom. ${ }^{3}$ As much as possible we have an obligation to try and understand, and, where possible, accommodate cultural differences. Therefore an exploration of the interface between culture and attitudes toward brain death is warranted.

Cultures are maps of meaning through which people understand the world and interpret things around them. Deeply ingrained in the roots of a society, culture often influences attitudes toward treatments such as organ donation. In Canada, attitudes toward organ donation are closely associated with attitudes toward brain death because most organ donations are derived from cadaveric donors. Although brain death is widely accepted by health-care workers as a legitimate definition of death, from a non-medical perspective, the moment of death is not always self-evident. That is,

From the Department of Bioethicist, Mount Sinai Hospital and University of Toronto Joint Centre for Bioethics, Toronto, Ontario, Canada. Address correspondence to: Dr. Kerry Bowman, University of Toronto, Joint Centre for Bioethics, 88 College Street, Toronto, Ontario

M5G 1L4, Canada. Phone: 416-946-5057; Fax: 416-978-1911; E-mail: kerry.bowman@utoronto.ca Accepted for publication March 17, 2003.

Revision accepted November 11, 2003. 
the space between life and death is socially, culturally and politically constructed, and is fluid and open to dispute. Too often, however, health-care workers fail to acknowledge and sometimes misunderstand cultural differences that influence our views on death.

\section{The diagnosis of brain death in non-Western societies}

An important question related to brain death is "what is the period of transition between life and death?" It is not surprising that such questions evoke strong reactions in people. Even within Western culture, some question if we have created definitions, such as brain death, to solve important moral and social problems. (The terms "Western" and "non-Western" refer to philosophical and cultural distinctions rather than geographic. There are multiple layers of cultures and many differences within both Western and non-Western societies; neither is considered culturally monolithic).

Questions concerning the boundary between life and death have deep cultural roots in many societies. They appear in mythology, folklore and documents from medieval times. ${ }^{4}$ A recent study, for example, suggests that in Japanese society Shinto and Buddhism have strongly supported "natural" processes and approaches to dying. ${ }^{5}$ According to Buddhist belief, once a person has entered the cycle of life, aging, illness and death are inevitable. ${ }^{6}$ From a traditional Japanese perspective, a human being is the integration of body, mind and spirit. After death, they remain an integrated whole. The metaphorical centre of the body, kokoro, has traditionally been located in the chest. ${ }^{7}$ Therefore, removal of an organ from a brain dead human, especially from the chest, may be perceived as disturbing this integrated unit. ${ }^{8}$ A noted Japanese anthropologist theorizes that the Japanese find in every part of a deceased person's body a fragment of the deceased's mind and spirit. ${ }^{9}$ She concluded that the Japanese believe a dead person goes to the next world as a soul. This soul has its own body, senses and feelings similar to a living person. The dead body must remain whole. If some parts are missing, the soul becomes unhappy in the next world. ${ }^{9}$ Such latent yet formative cultural views are not specific to the Japanese. Although not homogeneous in their views, many Canadian aboriginal people are profoundly uncomfortable with organ donation. ${ }^{10}$ In many non-Western cultures, death is viewed as a social event rather than a scientific phenomenon. ${ }^{11}$

\section{The diagnosis of brain death in Western societies}

By contrast, the tendency to plan for and control major life events is a prominent feature of contemporary Western societies ${ }^{12}$ and appears to be strongest in
English-speaking countries. ${ }^{13}$ This leads many in the West to expect medical solutions to illnesses that once signaled the approach of death. Increasingly, death is perceived as a failure of medical care. Organ donation is often perceived as a way of improving health but also as a way of extending life or evading death. With a growing number of people who meet clinical criteria for organ donation, demand for such treatments can be powerful. Why has the West willingly accepted brain death and organ donation? What are the cultural, historical, philosophical and religious influences that have made them permissible in the West?

In the West, human beings have often been perceived as the blending of body and soul. Christianity has shaped the West as Buddhism, Shinto and Confucianism have shaped Japan. In Christianity, people are expected to respect the body after death, as it was an essential part of the person during life; however, a body without a soul is no longer considered a person. With regard to organ procurement, many Christians perceive the donation of one's organs as an act of love and generosity. ${ }^{14}$ The spiritual value of non-reciprocal giving is central to Christian belief. This, in part, may have contributed to large social acceptance of organ donation. In ancient Christianity, bodies and body parts were imbued with profound meaning and often considered capable of resurrection. ${ }^{4,15,16}$ As well, communion - the symbolic giving of "the body and blood of Christ" - may have contributed to Western cultural acceptance of organ donation.

Seventeenth century thinkers Bacon and Decartes are perceived by some as responsible for placing the "locus of the person" in the mind and for relegating the body to a secondary role. ${ }^{17}$ Summarized by I think therefore I am, this perception imbued the mind with social and ethical meaning but may have, in turn, devalued the body. The brain is the home of the rational and autonomous mind. At death, the mind leaves the body. From this perspective, once the house of the mind - the brain - dies the synthesis between mind and body ends. With this separation of body and mind comes death of the human being. ${ }^{18}$ Thus, many Westerners perceive organ procurement from brain dead persons as clearly ethical. This is reflected in the "presumed consent" stance of some European countries that brain dead patients are considered to be consenting to organ donation unless previously stated. ${ }^{19}$

\section{Brain death and the Canadian society}

Despite wide cultural and sometimes personal variations in views toward organ donation, in Canadian health care the procedure is frequently viewed exclusively in absolute and positive terms, such as "the gift of life." 
While organ donation may indeed provide the gift of life, what can be said about people who disagree with this position on metaphysical or cultural grounds? Are they wrong? In our enthusiasm to increase organ donation, it is essential that we not violate a fundamental tenant of Canadian society: respect for diversity. This includes respect for diverse opinions. ${ }^{20}$

If mandatory reporting of brain death is adopted in Canadian health care then it is critical that we are well prepared to truly understand and respect cultural differences. "Presumed consent" - proceeding with organ donation from a brain dead person unless he or she has previously specified - is an ethically dubious concept and in Canada may be truly problematic as it could create great trauma to families who are unaware of such a policy and find the practice unethical or abhorrent from a cultural point of view. Furthermore it could be challenged under the Canadian Charter of Rights and Freedoms. In a sophisticated and developed nation such as Canada, there is often resistance to exploring anthropological trends from a research perspective. Consequently, we may overlook the effects of culture on attitudes toward organ donation by exclusively examining more pragmatic explanations, exploring the organization of medical care, or the relationship between the health-care system and the public. As a result, we may greatly underestimate the effect of culture on Canadian attitudes toward organ donation. In turn tension and misunderstanding may arise if cultural differences are not identified and respected before we begin to discuss organ donation. Recognition of these differences is critical to the development of policies that are respectful of the diverse and pluralistic country that we value and in which we live. Education alone, will not ameliorate the effects of cultural differences. However, educating health-care providers about the depth and meaning of culture and the ways of respecting and negotiating differences is an excellent investment.

\section{References}

1 Dionat S. Cultural Diversity and the Challenge of Canadian Unity. An address by the President of the Privy Council and Minister of Intergovernmental Affairs, Collège Universitaire de St-Boniface St. Boniface: Manitoba; March 13, 1997.

2 Multiculturalism and Citizenship Canada. Canada Census Policy and Research Branch, 1994.

3 Section 34. Constitution Act. Canadian Charter of Rights and Freedoms, 1982.

4 Lock M. Twice Dead: Organ Transplantation and the Reinvention of Death. Berkely, California: University of California Press; 2002.
5 Tanida N. Japanese religious organizations' view on terminal care. Journal of Asian and International Bioethics 2000; 10: 34-7.

6 Armstrong K. Buddha. New York: Penguin Books; 2001.

7 Obnuki-Tierney E. Illness and Culture in Contemporary Japan: an Anthropological View. New York: Cambridge University Press; 1984.

8 Kimura R. Contemporary Japan (medical ethics, history of Japan). [cited 2003 April 8]. Available from: URL: http://www.bioethics.jp/bios-japanall.html.

9 Morioka $M$. Bioethics and Japanese culture: brain death, patients' rights and cultural factors. Eubios Journal of Asian and International Bioethics 1995; 5: 87-90.

10 Emory $M$. Native America calling, January 2001. Available at: http://www.nativeamericacalling.com.

11 Ikels $C$. Kidney failure and transplantation in China. Soc Sci Med 1997; 44: 1271-83.

12 Giddens A. Modernity and Self Identity: Self and Society in Late Modern Age. Cambridge: Polity Press; 1991.

13 Seale $C$. Changing patterns of death and dying. Soc Sci Med 2000; 51: 917-30.

14 Scorsone S. Christianity and the significance of the human body. Transplant Proc 1990; 22: 943-4.

15 Rainbow Paul. Essays on the Anthropology of Reason. Princeton: Princeton University Press; 1996.

16 Bynum $C W$. Fragmentation and Redemption: Essays on Gender and the Human Body in Medieval Religions. New York: Zone Books; 1991.

17 Lysaught MT. Contesting the boundary between life and death: organ transplantation and the identity of the Christian community. In: DeLong WR (Ed.). Organ Transplantation in Religious, Ethical and Social Context: No Room for Death. The Haworth Press Inc.; 1993: 73-89.

18 Pennock RT. Death of the self: changing medical definitions in Japan and the U.S. Kokusaigaku revyu. 1995; 7: 109-25.

19 Hartwell L. Organ Donation Policies Around the World; Contemporary Dialysis and Nephrology. 1999; December Edition.

20 Bowman KW, Richard SA. Culture, brain death and organ transplantation. Prog Tansplant 2003; 13: 211-5. 